\title{
INVITING GODS: CASES OF THEOPHANIES IN THE PGM COLLECTION ${ }^{1}$
}

\begin{abstract}
Summary: Theophanies are a structural element of every religion and are based, partly, on the effort to reinforce the religious credo of believers - the appearance of a god before the eyes of a human proves his existence and his power - and, partly, on the need of humans to reassure their faith, always seeking proofs. Probably the earliest description of a theophany is in the Epic of Gilgamesh but certainly the most impressive is the Homeric narration of the encounter between Athens and Ulysses under a tree, where they talk and laugh like old friends.

However, testimonies of theophanies can be also found on the margin of official religion, in the field of magic. The difference here is that god does not appear voluntarily but is compelled by the power of the magic rituals to reveal himself and serve human desires. In this paper, I intend to unfold the $P G M$ (Papyri Graecae Magicae) collection, and, bearing in mind its magico-religious syncretistic character and the multi-cultural and multi-religious environment of its Greco-Roman Egyptian origin, to describe the magical procedures aimed at the appearance of the god and then to analyze their underlying similarities and compare them with the "official" theophanies, in order to detect repeated motifs, influences or problems.
\end{abstract}

Key words: Theophanies, epiphanies, Magical Papyri, motifs, purity, danger, star, isolation, hospitality, sacred meal

\section{INTRODUCTION}

The necessity of god's existence seems to be essential for human nature, for reasons that have already been explored. Inevitably, the traditions of almost every religion have to demonstrate some theophanies and epiphanies in order to convince the unfaithful and to enhance their adherents' religious credo and reward their faith. The divine-

${ }^{1}$ This article has been written within the frame of the project FFI2011-27438 of the Spanish Ministry of Economy and Competitiveness and reproduces my contribution to the International Conference Sapiens Ubique Civis II held in Szeged in 2014. I am grateful to all the participants for their contributions. 
human encounter was not described simply to enhance a particular individual, but was always carried out with larger societal and covenantal concerns in mind, as Savran states. ${ }^{2}$ These limited manifestations are of particular importance, because they somehow minimize the difference between human and divine and bridge the gap between them. In theophanies, the place, the time, the form of the manifestation and its purpose were usually left to the discretion of the deity.

Theophanies also appear in the realm of magic. However, here the manifestation of the god loses the elements of suddenness and unpredictability, because it is not the god who takes the initiative to be seen but he is compelled to do so and is forced to be manifested by magical formulas, incantations and voces magicae. In magic, the deity is usually called in order to reveal the future and to guarantee a prosperous life and his support and protectiveness once and forever to the practitioner. Although it does not have a malicious purpose, the idea of a god compelled to serve human desire seems to cross the permitted borders, was branded as hybris and was therefore prohibited, being exiled to the weird world of magic. This is of course an important distinction between religious theophanies and magical theophanies. However, the greatest testimony of magic in antiquity, the Greek Magical Papyri (hereafter PGM) collection, is full of such magical rituals.

Let me begin with some introductory remarks on Magical Papyri in general, for those who are not familiar with the context of magic. The $P G M$ is a body of papyri from Greco-Roman Egypt. They contain a variety of magical spells and formulas, hymns and rituals. The majority of them date back from the 2 nd century AD to the 5th century AD. Created in the multi-cultural and multi-religious environment of Greco-Roman Egypt, they are a unique testimony and their editions, especially that of Preisendanz, ${ }^{3}$ which incorporated almost all, have offered much to the understanding of the magical-religious amalgam of the Roman Imperial period. At the same time, however, the $P G M$ is a collection characterized mainly by its lack of homogeneity. Written over a period of more than three hundred years, by different hands and under unknown circumstances, most of the papyri contain a variety of recipes and magic spells that do not allow us to easily classify them and draw conclusions about their origin and use.

This paper aims to examine a magical ritual called "the spell of Pnouthis" aiming at the apparition of a deity and other cases of theophanies from the same collec-

\footnotetext{
${ }^{2}$ See SAVRAN, G.: Encountering the Divine: Theophany in Biblical Narrative [JSOTSup 420]. London 2005, 2.

${ }^{3}$ See PREISENDANZ, K.: Papyri graecae magicae. Die griechischen Zauberpapyri (PGM). Vol. III. Stuttgart 1973-1974; BETZ, H. D. (ed.): The Greek Magical Papyri in Translation, Including the Demotic Spells. Chicago-London $1992^{2}\left(1986^{1}\right)$; there is also a remarkable edition in Spanish with an interesting introduction, see Calvo Martinez, J. L. - SAnChez Romero, M. D.: Textos de Magia en Papiros Griegos. Traducción de Papyri Graecae Magicae de Preisendanz- Heinrichs. Madrid 1987; The rest of the papyri are included in a supplementum, see DANIEL, R. W - MALTOMINI, F.: Supplementum Magicum. Vol. I-II [Abhandlungen der Rheinisch-Westfälischen Akademie der Wissenschaften. Sonderreihe, Papyrologica Coloniensia, XVI.1-2]. 1990-1992; BRASHER, W. B.: The Greek Magical Papyri: an Introduction and Survey; Annotated Bibliography (1928-1994). ANRW II 18.5. Berlin - New York 1995, 3380-3684.
} 
tion. Bearing in mind its syncretistic character and the special environment in which it was produced, I will describe the magical procedures aimed at the appearance of the god and will then analyze some basic elements or repeated motifs, underlying striking similarities compared to "official" theophanies, in order to detect influences, problems or differences.

The issue of terminology and the search for a homogeneous term to describe a religious concept is especially central when venturing into a comparative study. Epiphany comes from the Greek verb phainein and refers to the visible manifestation of a divinity or to an experience of a sudden insight or revelation. The term theophany belongs to Christian theology, but I prefer to use it since I believe it implies and better highlights, in addition to the verbal interaction, the presence of a visual component, i.e. the physical appearance or personal manifestation of a god to a person. In this paper I will focus mostly, but not exclusively, on the anthropomorphic manifestation. I will discuss texts that speak of visitations, of actual meetings between humans and deities, and the interaction between the two spheres. However, I must admit that the boundaries between these two words are not so clearly separated. ${ }^{4}$

\section{THE SPELL OF PNOUTHIS (PGM I $42-195)^{5}$}

We will take as our point of departure the so-called spell of Pnouthis of $P G M$ I. The papyrus dates to the 3rd-4th centuries. The Spell of Pnouthis is a magical letter of the famous scribe, Pnouthis, to a man named Keryx, and contains instructions for acquiring an assistant daemon. I have chosen this fragment because it is one of the most detailed spells in the collection and has given rise to a plethora of articles and monographs. ${ }^{6}$

\footnotetext{
${ }^{4}$ The distinction between epiphany and theophany has raised a long debate and the studies, insofar, reveal the confusion surrounding the terminology for these words. Furthermore, they assume different meanings in different religious contexts. H. S. VERSNEL (What did Ancient Man See When He Saw a God? Some Reflections on Greco-Roman Epiphany. In VAN DER PLAS, D. [ed.]: Effigies Dei: Essays on the History of Religions. Leiden 1987, 42-55) gives the definition: "The term epiphaneia denotes two things: the personal appearance of a god and his miraculous deeds." But the expression "personal appearance" is ambiguous. The distinction made by Westermann in the frame of the Jewish tradition between theophany, which he defines as God's appearance for the purpose of self-revelation to convey a message to his people through a mediator, and epiphany, which is defined as his appearing in order to help his people, does not solve the problem. Polak differentiates theophany as displaying an "outside perception", while simple divine address involves what Polak calls "an inner light". See POLAK, F.: Theophany and Mediator: The Unfolding of a Theme in the Book of Exodus. In VERVENNE, M. (ed.): Studies in the Book of Exodus: Redaction-Perception-Interpretation. Leuven 1996, 113-147. Schmidt and Nel distinguish between theophany and epiphany as denoting, respectively, divine presence and divine power. See SCHMIDT, N. F. - NEL, P. J.: Theophany as Type-Scene in The Hebrew Bible. Journal for Semitics 11 (2002) 256-281. Harvey defines theophany as "the temporal and spatial manifestation of God in some tangible form". See HARVEY, V.: A Handbook of Theological Terms. New York 1964, s.v "Theophany". See also BARR, J.: Theophany and Anthropomorphism in the Old Testament. VTSup 1 (1959) 31-38. It would be beyond the scope of this essay to analyze in length all the theories about these terms and offer more bibliography.

${ }_{6}^{5}$ See Betz (n. 3) 4.

${ }^{6}$ Useful for some points I am going to discuss here is the following article: SCIBILIA, A.: Supernatural Assistance in the Greek Magical Papyri: The Figure of the Parhedros. In BREMMER, J. N. -
} 
[Пvov́] $\theta \varepsilon \omega \varsigma$ i $\varepsilon \rho$ o $\gamma \rho \alpha \mu \mu \alpha \tau \dot{\varepsilon} \omega \varsigma \pi \alpha \rho \varepsilon \delta \rho o \varsigma$.

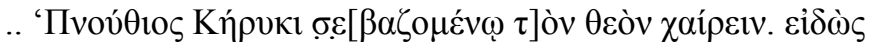

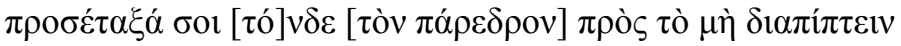

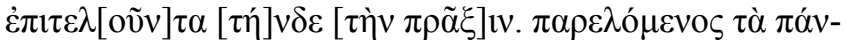

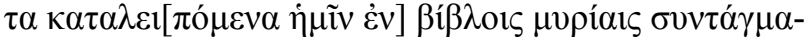

$\tau \alpha,[\tilde{\varepsilon}] v \pi \alpha \dot{v}[\tau \omega v] \lambda \eta \alpha$.

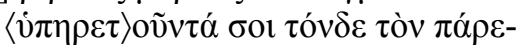

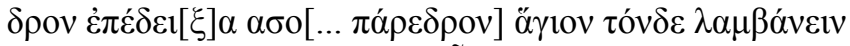

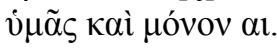
. $\mathrm{s} \varsigma, \tilde{\omega} \varphi^{\prime} \lambda \varepsilon \dot{\alpha} \varepsilon \rho i ́ \omega v$

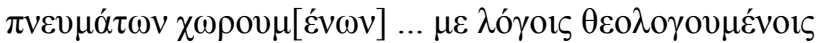

$\pi \varepsilon i ́ \sigma \alpha \nu \tau \varepsilon \varsigma \varepsilon \sigma o \mu[$ $v \tilde{v}] v \delta \dot{\varepsilon} \alpha \dot{\alpha} \varepsilon \varepsilon \varepsilon \mu \psi \alpha \tau \eta \dot{\eta} v \delta \varepsilon \tau \grave{\eta} v$

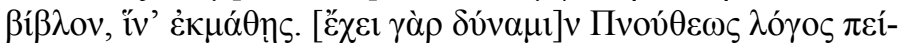

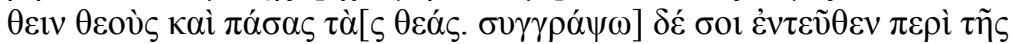

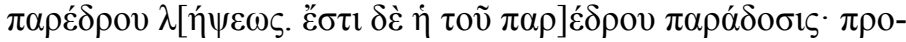

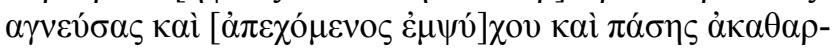

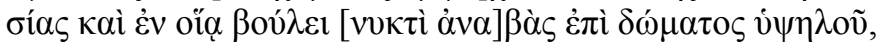

$\dot{\varepsilon} v \delta \varepsilon \delta v \mu \varepsilon \dot{v} v \circ \varsigma \alpha \alpha \theta \rho \tilde{\omega} \varsigma[$

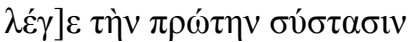

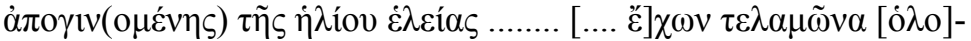

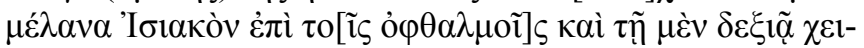

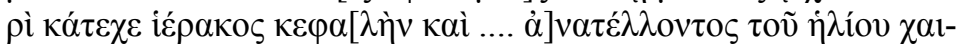

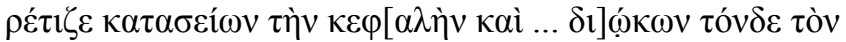

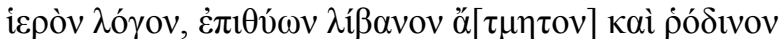

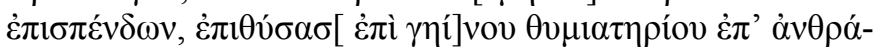

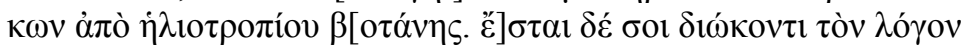

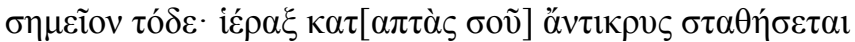

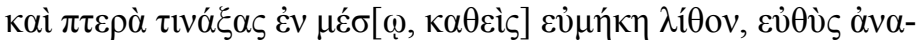

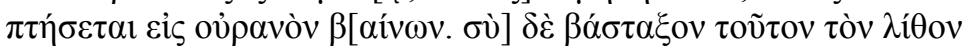

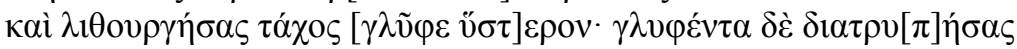

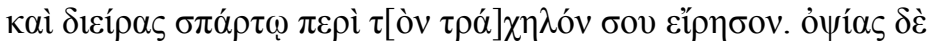

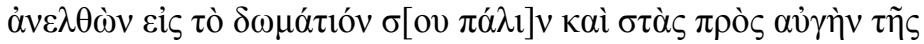

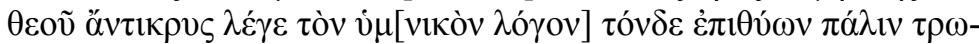

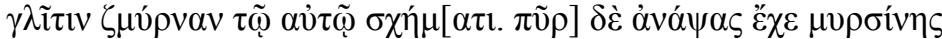

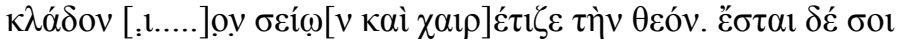

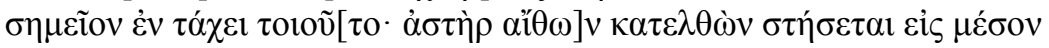

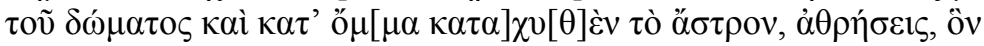

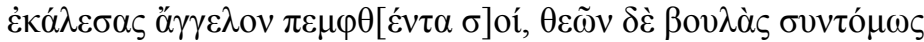

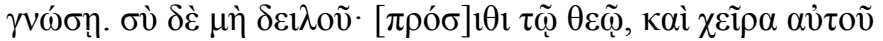

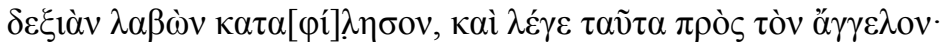

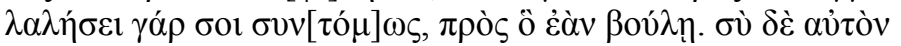

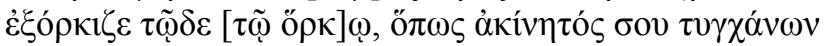

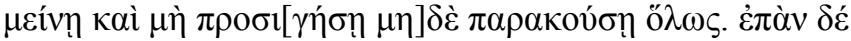

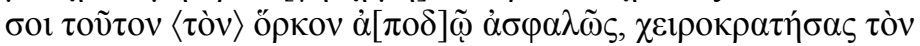

VeEnstra J. N. (eds.): The Metamorphosis of Magic from Late Antiquity to the Early Modem Period. Leuven 2002, 71-86, esp. 81-82. 


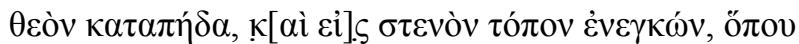

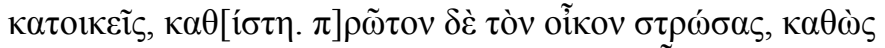

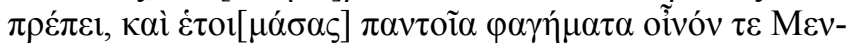

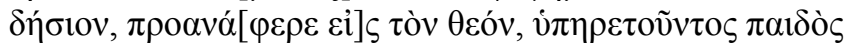

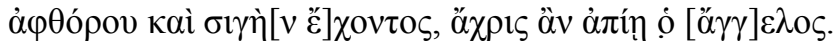

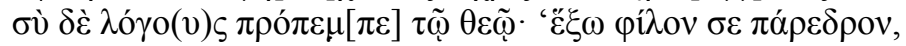

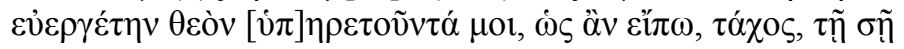

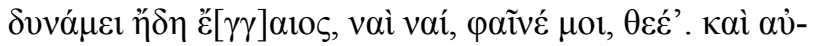

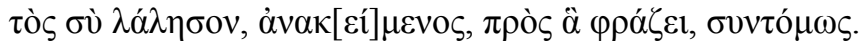

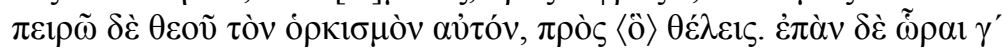

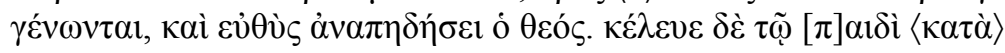

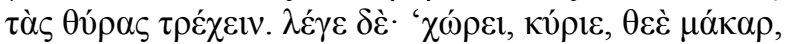

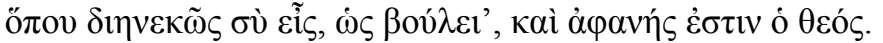

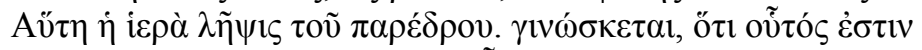

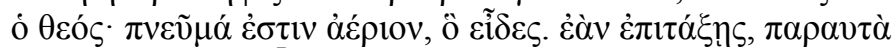

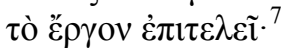

\section{The spell of Pnouthis, the sacred scribe, for acquiring an assistant:}

... Pnouthios to Keryx, a god[-fearing man], greetings. As one who knows I have prescribed for you [this spell for acquiring an assistant] to prevent your failing / as you carry out [this rite]. After detaching all the prescriptions [bequeathed to us in] countless books, [one out of all...] I have shown you this spell for acquiring an assistant [as one that is serviceable] to you... for you to take this holy [assistant] and only... O friend of aerial / spirits [that move]... having persuaded me with god-given spells... but [now] I have dispatched this book so that you may learn thoroughly. For the spell of Pnouthis [has the power] to persuade the gods and all [the goddesses]. And [I shall write] you from it about [acquiring] an assistant.

[The] traditional rite [for acquiring an assistant]: After the preliminary purification, / [abstain from animal food] and from all uncleanliness and, on whatever [night] you want to, go [up] onto a lofty roof after you have clothed yourself in a pure garment... [and say] the first spell of encounter as the sun's orb is disappearing... with a [wholly] black Isis band on [your eyes], and in your right hand / grasp a falcon's head [and...] when the sun rises, hail it as you shake its head [and]... recite this sacred spell as you burn [uncut] frankincense and pour rose oil, making the sacrifice [in an earthen] censer on ashes from the [plant] heliotrope. And as you recite the spell there will be / this sign for you: a falcon will [fly down and] stand in front of [you], an after flapping its wings in [mid-air and dropping] an oblong stone, it will immediately take flight and [ascend] to heaven. [You] should pick up this stone; carve it at once [and engrave it later]. Once it has been engraved, bore a hole in it, pass a thread through

\footnotetext{
${ }^{7}$ Preisendanz (n. 3) 5-7.
} 
and wear it around your neck. But in the evening, / go up to [your] housetop [again] and, facing the light of the goddess, address to her this [hymnic spell] as you again sacrifice myrrh troglitis in the same fashion. Light [a fire] and hold a branch of myrtle... shaking it, [and salute] the goddess.

At once there will be a sign for you like this: [A blazing star] will descend and come to a stop in the middle / of the housetop, and when the star [has dissolved] before your eyes, you will behold the angel whom you have summoned and who has been sent [to you], and you will quickly learn the decisions of the gods. But do not be afraid: [approach] the god and, taking his right hand, kiss him and say these words to the angel, for he will quickly respond to you about whatever you want. But you / adjure him with this [oath] that he meet you and remain inseparable and that he not [keep silent or] disobey in any way. But when he has with certainty accepted this oath of yours, take the god by the hand and leap down, [and] after bringing him [into] the narrow room where you reside, [sit him] down. After first preparing the house / in a fitting manner and providing all types of foods and Mendesian wine, set these before the god, with an uncorrupted boy serving and maintaining silence until the [angel] departs. And you address preliminary (?) words to the god: "I shall have you as a friendly assistant, a beneficent god who serves me whenever I say, 'Quickly, by your / power now appear on earth to me, yea verily, god!'”

And while reclining, you yourself quickly speak about what you propose. Test this oath of the god on [what] you wish. But when 3 hours have passed, the god will immediately leap up. Order the boy to run [to] the door. And say, "Go, lord, blessed god, / where you live eternally, as you will," and the god vanishes.

This is the sacred rite for acquiring an assistant. It is acknowledged that he is a god; he is an aerial spirit which you have seen. If you give him a command, straightway he performs the task...

The spell continues with a list of all the tasks that the paredros can carry out under the orders of the magician.

Let me note at this point that The spell of Pnouthis has provoked a lengthy debate among scholars. The problem lies in the two words the scribe uses alternately, theos and angelos; and deprives us from the certainty whether the divine being is a god or simply a messenger of him. Various arguments have been expressed about this major interpretative problem. Ciraolo argues that "the term ó $\gamma \gamma \varepsilon \lambda \circ \varsigma$ is used interchangeably with $\theta \varepsilon$ ó $\zeta$, essentially as synonyms, and the word does not appear to have any special connotations." "Similarly, according to O’Neil: "this angel or messenger

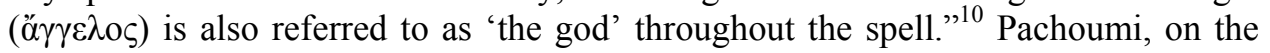

\footnotetext{
${ }^{8}$ The translation is taken from BETZ (n. 3) 4-6. Betz used the edition of PREISENDANZ (n. 3).

${ }^{9}$ See Ciraolo, J.: Supernatural Assistants in the Greek Magical Papyri. In MEYER, M. MireCKI, P. (eds.): Ancient Magic and Ritual Power. Leiden 1995, 279-295, esp. 283.

${ }^{10}$ See O'Neil in Betz (n. 3) 5.
} 
other hand, exploring comparative material, concludes that we cannot reject the possibility of two different entities in the spell. ${ }^{11}$

\subsection{A Solitary Experience}

The first element we can notice and have to stress is that it is about a solitary experience. The protagonist needs to be alone, preferably in an isolated area. The meeting with the deity is perceived as an individual and not a collective experience. The sense of separation from everyday life is a necessary precondition for the divine meeting and prepares the recipient of the extraordinary experience. In this case, the area required is a roof, probably because the practitioner addresses a celestial divinity and the roof is the highest place that someone can easily reach. From the roof, you can also have an unobstructed view of the heavens. In addition, it is of utmost importance to be alone and a roof serves this purpose.

In $P G M$ XII 38, where the god Eros is invoked, we read "on the third day, place another chick on the altar; while conducting this portion of the ritual, consume the chick by yourself, allowing no one else to be present." In a spell of attraction (PGM IV 2649) between the instructions given we read, "go up to a lofty roof, and make the offerings". A charm for a direct vision of Apollo (PGM VII 728) starts "in a groundfloor room without light". Elsewhere (PGM IV 170) it is written: "at whatever sunrise you want / (provided it is the third day of the month), go up to the highest part of the house and spread a pure linen garment on the floor. Do this with a mystagogue."

Regarding this element, we should comment that isolation was not a prerequisite in ancient Greece. ${ }^{12}$ The religious credo of the Greeks can be described as peculiar, because they seemed to believe that the gods were living among them. They had chosen as their home the highest Greek mountain and very frequently came down and lived amongst mortals. Artemis hunts in Arcadia, she takes her bath in a river of Arcadia, on some days Apollo resides in his Oracle in Delphi, Dimitra serves the oikos of Celeus, Zeus is almost always on earth trying to seduce a mortal girl, etc. In Homer, gods are known more by their power than their discrete personalities. ${ }^{13}$ In the Iliad, theophanies (or epiphanies) are very frequent and often influence the course of the battle and the myths, which suggests that Olympians did not have any problems revealing their divine nature wherever and whenever it was needed in order to fulfill their plans. However, they were not visible to all alike, for example, Odysseus but not Telemachus could see his helper, Athena. In the classical Athens of the late 5th century

${ }^{11}$ See PAChoumi, E.: Divine Epiphanies of Paredroi in the Greek Magical Papyri. GRBS 51 (2011) 155-165, esp. 164-165.

${ }^{12}$ A highly important monography that discusses many aspect of this topic is recently offered by Petridou, G.: Divine Epiphany in Greek Literature and Culture. Oxford 2016.

${ }^{13}$ See Lane Fox, R.: Pagans and Christians. San Francisco 1986, 113; see also PlatT, V.: Facing the Gods: Epiphany and Representation in Graeco-Roman Art, Literature and Religion. Cambridge New York 2011; Bremmer, J. N. - Erskine, A. (eds.): The Gods of Ancient Greece: Identities and Transformations [Edinburgh Leventis Studies 5]. Edinburgh 2010. 
$\mathrm{BC}$, the presence of the gods had become a convention to sophisticated minds and it was an experience exploited in abundance in Greek drama. Therefore, I believe the term theophaneia cannot be successfully adapted to the case of Greek religion. It must be stressed that in all these divine activities, gods took the human form so they were not easily identifiable by the mortals.

However, the ancient Greeks had a festival called Epiphany. They celebrated the appearance of a god to a human, at some specific place and the hymns composed by Callimachus between the 270s and late 240s BC, threw a bridge between literature and religious life. Three of his hymns, especially, were associated with civic festivals, although their style makes it hard to confirm that they were meant for recitation on the festival's day. Each, however, begins with a scene in which the god or goddess is about to be present among the onlookers. ${ }^{14}$ Similarly, in the context of the Delphic festival of Theophaneia, according to Himerius, the participants called Apollo to appear to them via a paean of Alcaeus. ${ }^{15}$

Prayers and invocations also match the language of hymns and they also throw a bridge between literature and life. The lyrics of the great Attic dramatists allow us insight into appeals to a god to "appear" and their models were certainly daily hymns and prayers of the cult. A very eloquent example comes from Sophocles in the Ajax, where the chorus prays to Apollo to come "with kindly mind and in easily recognizable form". 16 "In Aristophanes, as in Sappho, gods are invited to assist human celebrations and to drink with the participants of peaceful rustic festivals. These prayers call on the gods by names and they request in advance the manner or mood in which the god should appear," claims Lane Fox. ${ }^{17}$

In the Egyptian religion, a characteristic feature is the variety of the forms in which the unseen intervenes. The Egyptian gods are not monophysites. ${ }^{18}$ The gods could express their selves through a confusing multiplicity of forms and almost never limited themselves to one form but changed their manifestations at will. In this land, sacred animals, earthly images and statues were worshipped as incomplete manifestations or partial revelations of the gods. These manifestations served to make the god more accessible to the believer. The true form of the god, the complete and perfect physical manifestation is rarely revealed to humankind, and the worshipper perhaps has the opportunity to meet the god in the next world..$^{19}$ Although it is clear that the true form of the deity was hidden to man, the Egyptian gods were not antisocial and their manifestations always took place in a social framework. A serious restriction in the case of Egyptian gods is that we cannot speak about exclusively anthropomorphic manifestations, but even with this restriction, it remains evident that they were ap-

\footnotetext{
${ }^{14}$ See Lane Fox (n. 13) 114; Vestrheim, G.: The Poetics of Epiphany in Callimachus' Hymns to Apollo and Pallas. Eranos 100 (2002) 175-185.

15 Petridou (n. 12) 276.

${ }^{16}$ See LANE FOX (n. 13) 116.

${ }^{17}$ See LANE FOX (n. 13) 116.

${ }^{18}$ See Eyre, J. C.: Belief and the Dead in Pharaonic Egypt. In MU-CHOU, P.: Rethinking Ghosts in World Religion. Leiden-Boston 2009, 36.

${ }^{19}$ See DAVID, A. R.: Religion and Magic in Ancient Egypt. London 2002, 56.
} 
proachable and willing to make their presence on earth noticeable. We should not forget that Egyptian people considered each king a god, descended, according to mythology, from the times of the gods.

In studying the case of the Hebrew religion we should bear in mind its monotheistic doctrine, which differentiates it radically from all the other religions. Thus, the uniqueness of its god attributes to him an unsociable nature and its manifestations are extremely rare. In his book Encountering the divine, ${ }^{20}$ G. Savran has already emphasized this in biblical scenes, counting many cases where the protagonist is separated from his family or from other members of society before meeting god. For example, the angel appears to Elijah in $K g s 19.5$ after he has dismissed the servant, and Manoah's wife is alone on both occasions when the angel appears to her. ${ }^{21}$ The fact that this was a highly private experience and the focus on the solitary aspect of the theophany suggests that in the Jewish religion the appearance of the divine is antithetical to human company. This solitude also increases the sense of mystery surrounding the encounter.

Of course, we should not underestimate the influence of mystery cults, which took place in isolation and psychological abstraction, outside the normal sphere of reality, assuming this antisocial character. Magic can be described as a mystical experience from this perspective, but the objection could be that mystic cults were not exclusively performed or experienced individually. However, they excluded the uninitiated and they beheld a secret and, some of them, a marginal character. Moreover, the secrecy implied by separation could also be seen as a necessity for the magicians. Magic, even if widespread, was illegal and therefore prohibited. The magical rituals had to be performed hidden from curious and dangerous eyes.

\subsection{Purity}

The $P G M$ provides elaborate details regarding magical performance. There is a high concern for purity in both the rituals of preparation and reception. Central to these rules are prohibitions concerning foods and sexual behavior forbidden to the magician, to avoid pollution of the ritual. The preparation for the magical adjuration included imposing abstinence, fasting and pure clothes or garments. The collection of the $P G M$ often features the phrase "keep yourself pure" and describes cleansing procedures before the practice of magic. ${ }^{22}$ The magician's state of ritual purity and pre-

${ }^{20}$ See SAVRAN (n. 2) 14-18.

${ }^{21}$ See SAVRAN (n. 2) 14.

${ }^{22}$ See also $P G M$ I 40-42, PGM IV 26-29, PGM IV 733-737. Please note that the citations are exemplary and not exhaustive. For a more detailed analysis of the cleansing procedure in the $P G M$, see ZOGRAFOU, A.: Être pur pour réussir: le conditionnement de l'efficacite rituelle dans les $P G M$ and Blanco Cesteros, M. - Chronopoulou, E.: The Irresistible Attraction of Purity: Accusations of Religious Transgression in Magical Texts from Late Antiquity (both forthcoming in CARBON, M. - PEELS, S. [eds.]: Katharos: Concepts of Purity and Rituals of Purification in the Ancient Greek World. Liège 2017); SCIBILIA (n. 6) 81. 
paredness provides an exemplar and indicates the state of mental and physical perfection and preparation essential for the performance of the magical ritual.

It is an often-repeated cliché that the Greeks had no sacred book. But the absence of one single Panhellenic scripture does not mean that the Greeks had no sacred texts at all. It is well known that they had a plethora of texts that regulated and structured the performance of religious rituals. Most of these sacred regulations are epigraphically transmitted. Purity regulations were ever-present in Greek sanctuaries, addressing very cosmic matters. "They provide lists of objects that are prohibited in sanctuaries and enumerate different sources of pollution, such as sexual intercourse, menstruation, contact with a corpse, or even certain foods, listing the number of days the polluted should keep away from the sanctuary and the ways they can purify themselves" writes I. Petrovic ${ }^{23}$

Concerning purity regulations in Greek religion I have little to add beyond what Robert Parker and other scholars have said on the subject. ${ }^{24}$ But the fact that the practitioners feel the same need to be purified before the eyes of the god, even if the magical ritual is itself an "unclean" practice is very interesting. Fasting and abstinence from sexual intercourse are always a secure path to the pure status of the pious person. This also draws attention to the fact that in almost all the magical rituals described in the papyri, even the briefest, the scribe feels the necessity to add that the practitioner should perform them in a state of purity, giving instructions for that purpose. And we should not forget that fasting is a kind of separation from everyday life.

Fasting is strongly linked with the condemnation of sarcophagy, which is connected with the teaching of Orpheus in the Greek world. Almost from Aristophanes' time, poems attributed to Orpheus circulated, condemning the murdering of animals, either for food or as sacrifices. ${ }^{25}$ The most famous vegetarians were Pythagoras and Empedocles, although there is a long debate about whether they abstained from meat occasionally or permanently. However, the prohibition of sarcophagy is central in the cult prohibitions and is related with exceptional moments, especially when a human is to have any kind of contact with the divine, such as entering a temple, attending a sacrifice, or waiting for an epiphany.

\footnotetext{
${ }^{23}$ Petrovic, I.: Callimachus and Contemporary Religion. In ACOSTA-HugheS, B. - LeHnus, L. STEPHENS, S. (eds.): Brill's Companion to Callimachus. Brill 2011, 268.

${ }^{24}$ For a catalogue and discussion of purity regulations as a group, see PARKER, R.: Miasma: Pollution and Purification in Early Greek Religion. Oxford 1983. See also PARKER, R.: What Are Sacred Laws? In HARRIS, E. M. - RUBINSTEIN, L. (eds.): The Law and the Courts in Ancient Greece. London 2004, 57-70; LuPU, E.: Greek Sacred Law. A Collection of New Documents. Leiden - Boston 2005; CHANIOTIS, A: Reinheit des körpers - Reinheit des sinnes in den griechischen kultgesetzen. In ASSMANN, J. SundermeIER, T. (eds): Schuld, Gewissen und Person [Studien zum Verstehen fremder Religionen 9]. 1997, 142-179. On purity of mind in Greek religion, see CHANIOTIS, A. - PleKET, H. W. - STROUD, R. S. - Strubbe, J. H. M.: Religion. Purity of the Mind as Requirement in Sacred Laws. SEG 47-2340, 1997.

${ }^{25}$ See Borgeaud, P.: Greek and Comparatist Reflexions on Food Prohibitions. In FreVEL, C. Nihan, C. (eds.): Purity and the Forming of Religious Traditions in the Ancient Mediterranean World and Ancient Judaism. Leiden-Boston 2013, 261-287, esp. 262.
} 
Diogenes Laertius (VIII 33), ${ }^{26}$ following Alexander Polyhistor and, again, Aristotle says:

Purification is by cleansing, baptism and lustration, and by keeping clean from all deaths and births and all pollution, and abstaining from meat and flesh of animals that have died, mullets, gurnards, eggs and egg-sprung animals, beans and other abstinences prescribed by those who perform mystic rites in the temples. ${ }^{27}$

Porphyry, in his work De abstinentia, ${ }^{28}$ gives a conceptualization of purity defining it as an "absence of mixture", amixia, whereas pollution is the result of such a mixture: not to mix the same with the other, or with the opposite. Thus, consuming the dead body of an animal is a mixing of life and death. The principle is that purity consists of abstaining from mixing, agneia. Of course, this principle is not only applied to food, but starting with ritual prescriptions related to food, it logically leads to the condemnation of hetero- or homosexual unions. From a male perspective, sexual intercourse, which is a mixture of masculine and feminine, "feminises" the soul and the sperm that dies in the process is also a mixture of death and life.

It is considered that Greek had been strongly influenced by the Egyptians. The first prohibition in Egypt concerns fishes, ${ }^{29}$ mainly which come out of the sea: this abstention has to do with the fact that such fishes come from elsewhere, from outside, and in certain rituals fish and birds are identified with the enemies of Egypt, with "foreign invaders". However, when talking about prohibitions, we are talking about occasional, and not absolute or permanent prohibitions. Fish is not systematically avoided as food in Egypt and some fishes that are prohibited in a certain area in Egypt are consumed elsewhere in the country. ${ }^{30}$ It is known about the Egyptians' prohibitions that they abstained from any fish, solipedic quadrupeds, or fissipedic or non-horned ones. They also abstained from carnivorous birds. Many even abstained from any animal, without exception, and this is valid for all priests during the times when purity is permanently required. ${ }^{31}$ What is more interesting is in Chapter 64 of the Book of the Dead, where it says: "this formula should be read when pure and blameless, without having eaten small herd or fish, and without having had sexual relationship with a woman."

In the Jewish religion things were a little more complicated. As Origen (Comm. Rom. 9. 36. 1-2) highlighted, the Jewish scriptures did not specifically forbid eating

\footnotetext{
${ }^{26}$ See Diogenes Laertii, Vitae Philosophorum. Critical edition of the Greek text by H. STRAINGE LONG. Oxford 1964.

${ }^{27}$ Diogenes Laertius, Lives of Eminent Philosophers. Trans. by R. D. HICKS [LCL 184]. Cambridge, MA 1925, I 33. 7.

${ }^{28}$ See Porphyry, On Abstinence from Animal Food. Trans. by TAYLOR, TH., ed. by WYNNE-TYSON, E. London 1965.

${ }^{29}$ See BorgeAud (n. 25) 261-287. See also PILSBURY, J.: Food in the Ancient World. Westport 2006.

${ }^{30}$ See Baetens, G.: The Mummified Fish of Esna: a Case Study in Animal Worship. GM 239 (2013) 17-24; DARby, W. - Ghalioungui, P. - Grivetti, L.: Food: the Gift of Osiris. London 1977; BLANCO-CHRONOPOULOU (n. 22).

${ }^{31}$ See BorgEAUd (n. 25).
} 
meat. Jewish Law prohibits various types of unclean meat including pork. Furthermore, the proper preparation of meat, such as draining the blood, is equally important. ${ }^{32}$ Other texts specifically describe abstinence as avoiding meat and wine. Thus, Joseph and Aseneth $^{33}$ mentions Joseph avoiding Egyptian meat and wine because he considers them idolatrous. The Book of Daniel narrates Daniel and his friends eating only vegetables in order to maintain their purity. These stories of traditional Jewish heroes could serve as examples and sources of inspiration for Jews in a Pagan and Gentile environment. ${ }^{34}$ This evidence leads us to consider the dietary prohibitions of Jews as one of the main ways of public identification. Undoubtedly, Jews also believed that purity is linked with food restrictions, especially those of meat and wine. The remarkable point in this case is that they adopt these prohibitions on a permanent basis and not occasionally. We should not forget either that two Gospels, of Lucas and Matthew, show Jesus fasting in the desert before his encounter with the Devil.

But fasting is also a prerequisite in Jewish mysticism and magic. In Hekhalot Zutarti $^{35}$ Aquiva said "everyone who repeats this Mishnan and wishes to utter the name of God must fast for forty days...".

The Greek Magical Papyri finds something of a counterpart in the Jewish book Sepher Ha-Razim. ${ }^{36}$ The book is full of Greek terms, including incantations based on pagan prayers, indicating the close bonds between Jewish and Greek during this period. Its magical rituals are similar in style and content to the $P G M$. On its pages we can find the same concern for purity and perfection. ${ }^{37}$

\footnotetext{
${ }^{32}$ See Toney, C. N.: The Strong and Weak in Romans 14-15: Ending Divisions and Promoting Additions. Chicago 2007, 78.

${ }^{33}$ Ancient apocryphal expansion of the Book of Genesis. See PHILONENKo, M.: Joseph et Aséneth: Introduction, Texte critique, Traduction, et Notes. Leiden 1968; BOHAK, G.: Joseph and Aseneth and the Jewish Temple in Heliopolis. Atlanta 1996.

${ }^{34}$ See TONEY, C. N.: Paul's Inclusive Ethic. Resolving Community Conflicts and Promoting Mission in Romans 14-15. Tübingen 2008, 59-60.

${ }^{35}$ The Hekhalot and Merkavah manuscripts belong to Jewish mysticism and are written in Hebrew and Aramaic with several borrowings from Greek. This is an enigmatic work in terms of date and authorial identity. Schäfer, its editor, does not propose a specific date of composition but there is a long debate about it. The Hekhalot literature is post-rabbinical, produced some time between late antiquity - some believe in Talmudic times or earlier - and the early Middle Ages (200 CE-700 CE). The Hekhalot Zutarti, in particular, is concerned with the secret names of God and their powers. See SCHÄFER, P.: HekhalotStudien. Tübingen 1988.

${ }^{36}$ Sepher Ha-Razim was reconstructed by Mordecai Margalioth and translated into English by Micheal Morgan following the discovery of fragments from the Cairo Genizah in 1963. Margalioth dated Sepher Ha-Razim to the early 4th or late 3 rd century CE. Others argue for a later date. Alexander considers Margalioth's dating "too precise, and probably too early. The evidence suggests that the original form of Sepher Ha-Razim was composed in the fifth or sixth century CE, probably more towards the end of this period than the beginning. The place of composition, on linguistic grounds, is most likely to have been Palestine." See Morgan, M. A. (trans.): Sepher ha-Razim: The Book of Mysteries. Chico, CA 1983; Margalioth, M.: Sepher Ha-Razim: A Newly Discovered Book of Magic from the Talmudic Period. Jerusalem 1966; ALEXANDER, P. S.: Sefer Ha-Razim and the Problem of Black Magic in Early Judaism. In KLutZ, T. E. (ed.): Magic in the Biblical World: From the Rod of Aaron to the Ring of Solomon [JSNTSup 245]. London 2003, 170-190.

${ }^{37}$ The cited passages are exemplary and not exhaustive.
} 
Purify yourself from all impurity and cleanse your flesh from all carnality and then you will succeed. (First Firmament, 39)

Then go out on Sunday to the sea shore or to a river bank during the third hour of the night. Wear a new cloak and do not eat (the meat of) any animal, nor anything which yields blood (when slaughtered), and do not drink wine. (First Firmament, 223-235)

Cleanse yourself for three weeks from all fruit of the palm, from all kinds of animals, small and large, from wine, from (all) types of fish and from all (animals) that yield blood (when slaughtered); and do not approach a woman in her impurity, and do not touch anything which has died, and do not come near a leper or one afflicted by venereal discharge, even accidental, and guard your mouth from every evil word and from every sin. (Second Firmament, 5-10) ${ }^{38}$

In addition to these Jewish magical texts, there are some instances in Jewish literature where revelatory dreams and visions are obtained as a result of fasting. Daniel is the recipient of dreams and visions some of which were acquired through "prayer and supplication, with fasting, and sackcloth, and ashes" (Dan. 9:3).

The above survey clearly shows that magic, as almost all religions of that time, considered fasting and abstinence from certain types of food as a kind of spiritual purification and preparation needed for performing complicated magical formulas but also as a way to attract the deity. We can assume that this is an application of the Law of Similarity, similia similibus. Gods are considered pure, thus, in order to attract them, the practitioner must also be pure or at least purified.

\subsection{Meal-Hospitality}

Central in the spell is welcoming the god with a meal, which implies the hospital attitude of the practitioner. The meal should be abundant, offering all kinds of food and Mendesian wine and must be served by an uncorrupted boy. We can assume that the meal is offered in order to ensure the God's favor.

In literature, the motif of human hospitality to deities can be found in Homer's Odyssey, in Euripides' Bacchae, briefly in Vergil's Aeneid and, of course, in Ovid. About Homer and hospitality there are several publications, ${ }^{39}$ thus, I am going to focus on Ovid. Ovid narrates how Jupiter, Mercury and Neptune, visiting Hyrieus of Tanagra

\footnotetext{
${ }_{39}^{38}$ MORGAN (n. 36) 24, 41, 43, respectively.

${ }^{39}$ See BaILeY, M.: Homeric Guest-reception and Ritual Handwashing. American Philological Association Abstracts 1987, 126; EDWARDS, M. W.: Type-scenes and Homeric Hospitality. TAPA 105 (1975) 51-72; PEDRICK, V.: The Hospitality of Noble Women in the Odyssey. Helios 15 (1988) 85-101; REECE, S.: The Stranger's Welcome: Oral Theory and the Aesthetics of the Homeric Hospitality Scene. Ann Arbor 1992.
} 
in the guise of men rewarded their host with the gift of a long-desired son, Orion. ${ }^{40}$ Ovid also relates the story of Baucis and Philemon. ${ }^{41}$

In the religious context, ${ }^{42}$ we have the feast of Theoxenia, which honored the Dioskouroi. The details of this special festival are obscure. W. Burkert describes it as "in a closed room a table is spread and a couch with two cushions is prepared; two amphorae are set out, presumably filled with a food made from all varieties of grain, panspermia. Vase paintings and reliefs show the horsemen whirling through the air to the banquet. But snakes may also be shown curling round the amphorae. The festal eating by the human votaries follows." 43 This festival was celebrated in many parts of Greece, sometimes attaining the status of a major national festival as at Delphi where Apollo hosted. ${ }^{44}$ Burkert mentions also depictions of the Dioskouroi galloping through the air towards the two klinai prepared for them. ${ }^{45}$

Ovid's third narrative has been deliberately left for the last, after the description of Theoxenia, which places us in the religious context. It concerns Jupiter and Lycaon. ${ }^{46}$

There are several versions of the Lycaon myth already reported by Hesiod, told by several authors. According to Burkert, ${ }^{47}$ this is the explanatory myth behind the archaic festival of Lykaia, on the slopes of mountain Lykaion and the sacrifices that took place there. This myth brings us to the concept of sacrifice, which can also be explanatory in our case. We should bear in mind that the $P G M$ abounds with sacrifices and offerings. The sacrifices can also be seen as offerings of meal to the gods and sometimes the god is invited to attend the meal after the sacrifice with his followers. ${ }^{48}$ Therefore, we can consider the meal offered in the spell as a reflection or an imitation of a sacrifice. On the other hand, we should not reject the idea, identifiable in

\footnotetext{
${ }^{40}$ Ovid, Fasti. Trans. by J. G. Frazer. Rev. by G. P. Goold [LCL 253]. Cambridge, MA 1931, 5. 499-544.

${ }^{41}$ Ovid, Metamorphoses. Trans. by F. J. Miller. Rev. by G. P. Goold [LCL 42]. Cambridge,
} MA 1916, 8. 628-724.

${ }^{42}$ In the religious context, the meal is part of the sacrificial ritual and the sacrificial banquet became one of the most pertinent contexts of divine manifestations.

${ }^{43}$ See BURKERT, W.: Greek Religion: Archaic and Classical. Oxford 1985, 213.

${ }^{44}$ See MORRIS, S.: Taking Ancient Mythology Economically. Leiden - New York 1992, 104.

${ }^{45}$ For the ritual of Theoxenia, see also MOMMSEN, A.: Delphica. Leipzig 1878; JAMESON, M. H.: Theoxenia. In HäGG, R. (ed): Ancient Greek Practice from the Epigraphical Evidence. Proceedings of the Second International Seminar on Ancient Greek Cult, organized by the Swedish Institute at Athens, 22-24 November 1991. Stockholm 1994, 35-37; PARKER, R.: On Greek Religion. Ithaca-London 2011, 142-144; BURKERT, W.: Kleine Schriften VI: Mythica, Ritualia, Religiosa 3. Hrsg. von E. KRUMMEN. Göttingen 2011, 220-236; PETRIDOU (n. 12) 289-309. Parker stresses that "mortals might dine under the same roof as the gods, but the god has his own table" which means that "the difference in nature between man and good was irreducible". However, in our case is not clear if they dine together or separately.

${ }^{46}$ Ovid, Metam. 1. 214-243. Cf. n. 41.

${ }^{47}$ See BuRKERT, W.: Homo necans: The Anthropology of Ancient Greek Sacrificial Ritual and Myth. University of California Press 1983, 84-92.

${ }^{48}$ The link between sacrifice and banquet as a way of communication with gods is discussed in PARKER (n. 45) 127-144; It is argued that "the sacrifice opened a channel of communication between man and god and the mediator was the animal". The banquet after the sacrifice "forges bonds between man and god". But this spell gives us no evidence that the food offered was before sacrificed. As SCIBILIA (n. 6) 82 mentions the only animal sacrifice (bird) alluded in the text "takes the form of a mimetic evocation of the celestial) falcon". 
other Greek contexts, that the process of ritually sharing a portion with a god is a means of appeasing or compelling the god to cooperate.

Moreover, some inscriptions have been linked with the cult of Zeus Panamaros, ${ }^{49}$ attested from the 2 nd century BCE to the 4 th century CE. The inscriptions present the god as the host of the meal. Interesting are also the so-called "invitations to the kline of Sarapis". 50 Thirteen papyri with invitations to attend a sacred dinner with the god Serapis have been discovered until now. The thirteenth invitation is P.Oxy 3693. All the invitations were made in the name of a particular host, the god. ${ }^{51}$ The god was supposed to be present at the banquet. Excavations in sanctuaries have unearthed banquet rooms for about ten persons. As these cases depict the god as the host of the meal, they are eloquent about the relationship between the worshippers and the god and support the human belief that mortals and immortals can be co-diners.

In Egypt, also, the Daily Temple Ritual was carried out daily on a regular basis and in the same way in all temples throughout the country. Among the other ritual acts, the King had to consecrate the divine meal. At sunrise, the officiant would proceed to the sanctuary to present the meal. It included vegetables, wine, different kinds of bread and cakes, fruits and meat cut from the sacred cattle that belonged to the temple. The animal had previously been slaughtered in the temple precinct, according to strict ritual procedures. They put it before the statue of the god. These offerings symbolized the rebirth and the immortality of the King. The same ritual meal was presented at midday and in the evening. ${ }^{52}$

In the Book of Genesis, we come across the same motif of hospitality. In the biblical passage, Abraham is about to act as a servant to three heavenly guests - two were angels, and the other was the Lord, Jehovah. Abraham had neither seen nor heard their approach. He ran towards the men in spite of his age, and without knowing who they were, as in the Ovid's text. Abraham set baked bread before them, a whole calf and the dinner was served along with butter and curds (yogurt) and milk. This ignorance also led Sarah, then ninety-nine years old, to laugh at the annunciation of her pregnancy. I should stress that this scene takes place at noon, in a family environment and not in an isolated place. Although Sarah is not present from the beginning, we can explain her presence because the message that she is going to have a son was also for her. However, there is a very interesting detail in this biblical narrative that leads us back to the magical papyrus. God does not appear alone. He is accompanied by two angels, a fact that reminds us of the hermeneutical problem of the scene in the papyrus and the dubious alternate use of the word angelos and theos, that has led some scholars to consider that we have two entities.

\footnotetext{
${ }^{49}$ See HATZFeLD, J.: Inscriptions de Panamara. BCH 51 (1927) 57-122; on Zeus Panamaros see also PETRIDOU (n. 12) 99-100.

${ }^{50}$ See GILliam, J. F.: Invitations to the Kline of Sarapis. In HAnson, A. E. (ed.): Collectanea Papyrologica. Texts Published in Honor of H. C. Youtie. Bonn 1976, 317; GILL, D.: Trapezomata: A Neglected Aspect of Greek Sacrifice. HTR 67 (1974) 117-137.

${ }^{51}$ See WiLL, E.: Banquets et salles de banquet dans les cultes de la Grèce et de 1'Empire romain. In DuCREY, P. (éd.): Mélanges d'histoire ancienne et d'archéologie offerts à Paul Collart. Lausanne 1976, 353-362.

${ }_{52}^{5}$ See DAVID (n. 19).
} 
The last cases come from the Christian religion. The first one is from the Book of Revelation (3:20), ${ }^{53}$ where Christ knocks at the doors saying, "Behold, I stand at the door and knock. If anyone hears my voice and opens the door, I will come in to him and eat with him, and he with me." Of course, this fragment is an allegory. The door is the heart of every man where Christ seeks to enter and the dinner meal is the communion.

The second one (Vis. 5. 1) is dubious because the concept of a meal offered is based on the translation of the word $\kappa \lambda i v \eta v$ as dining couch. The fragment is as follows

While I was praying at home and sitting on my dining couch [ $\kappa \alpha \theta i ́ \sigma \alpha \nu \tau o s$

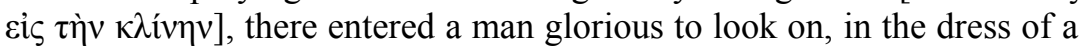
shepherd, covered with a white goatskin, with a bag on his shoulders and a staff in his hand. And he greetied me, and I greeted him back. And at once he sat down by me, and said to me, I have been sent by the most revered angel to dwell with you the rest of the days of your life. ${ }^{54}$

\subsection{The Appearance of a Star ${ }^{55}$}

Divine apparitions are usually foretold by or associated with celestial phenomena, such as remarkable stellar events or a spectacular skylight. This is quite understandable as popular thinking considers the celestial sphere as the dwelling of the god and interprets every unusual astronomical phenomenon as a divine sign. This was such a deeply rooted belief that many emperors and kings tried to take advantage of fortuitous astronomical phenomena for their political propaganda. The famous comet of 44 BCE that appeared shortly after the assassination of Julius Cesar on the Ides of March was propagandized as the apotheosis of Julius on the one hand and, on the other, as the signal of the novel era of Octavian ruling, who tried to present himself as a god on earth.

In "Mithras Liturgy" (PGM IV 475-829), the god's manifestation is very impressive.

Look in the air and you will see lightning bolts going down, and lights flashing, and the earth shaking, and a god descending, a god immensely great, having a bright appearance, youthful, golden-haired, with a white

${ }^{53}$ About the connection of this text with other divination texts, see AUNE, D.: The Polyvalent Imagery of REV 3.20 in the Light of Greco-Egyptian Divination Texts. In AUNE, E. - BRENK, F. E.: GrecoRoman Culture and the New Testament: Studies Commemorating the Centennial of the Pontifical Biblical Institute. Leiden - Boston 2012.

${ }^{54}$ PeTERSON, E.: Beiträge zur Interpretation der Visionen im Pastor Hermae. OrChrAn 13 (1947) 624-635. In this article, Peterson showed that the "revelatory apparatus" of the three Visions resembled Hellenistic divination, especially that of the PGM I. See also PETERSON, E.: Kritische Analyse der fünften Vision des Hermas. HJ 77 (1958) 362-369, rev. in IDEM: Frühkirche, Judentum und Gnosis. Freiburg i. Br. 1959, 271-276.

${ }^{55}$ For this part I have gratefully profited from Roy Kotansky and his article. Cf. KOTANSKY, R. D.: The Star of the Magi. Lore and Science in Ancient Zoroastrianism, the Greek Magical Papyri, and St. Matthew's Gospel. Annali di storia dell'esegesi 24 (2007) 379-421. I am indebted to him. 
tunic and a golden crown and trousers, and holding in his right hand a golden shoulder of a young bull... Then you will see lightning bolts leaping from his eyes and stars from his body (696-704). ${ }^{56}$

In the Corpus Hermeticum the gods "were visible in forms of stars with all their signs; while Nature had her members made articulate together with the Gods in her" (Corp. Herm. 3. 2). In the Testament of Solomon, which is dated to the 3rd or 4th century and which contains elements of Jewish magic we read the following conversation between Solomon and the demon "Accordingly I said to him: 'Under what star dost thou lie?' And he answered: 'In the very tip of the moon's horn, when it is found in the south. There is my star'."

In this light, it was not surprising that Jesus was thought by many as a divine king on earth and the Star of Bethlehem episode, which pointed to the birth of Jesus, in St. Matthew's Gospel is of great interest. Even if purely legendary, this famous Christmas story reflects the popular belief that a celestial sign accompanies the divine presence.

The first description of the star is its initial rising, then the Magi "see" the star again, where it is said this time to go before them and actually stop right above the Christ-child, pinpointing an individual house. Even more striking is that in the biblical narrative the first people who came to the begotten Son were the so-called "magi". Given the rivalry between magic and religion, the fact that Matthew chose to present few magi as the first worshippers of the true god, at least raises our attention. Herodotus uses the term "magi" to generically refer to a "sacerdotal caste" of Pre-Achaemenid Persia. ${ }^{57}$ The class of magi has been linked with the Zoroastrian religion as ritual specialists in sacrifices, incantations, divination and other sacerdotal rites. But long before the writing of the gospel "magi" had come to be related negatively with "magicians and charlatans", at least in Greek territory.

However, here the term "magi" does not seem to have a negative connotation and Matthew referred to them with the respectful interpretation of magus. And this is not without purpose. The tradition of the Zoroastrian magi talks about a prophetic star, but another significant text found in the Vahman Yast also appears embedded in the Pahlavi tradition. ${ }^{58}$ The document mentions a prophecy, a star's falling in connection with a divine birth. Widengren summarizes its cryptic wording as follows:

It is said... of the Saviour Husetar that his father was a prince, kai. Husetar in his turn is the begetter of the kai of religion. During the night when this kai is born there will be a sign to the world: a star falls from heaven and when this $k a i$ is born the star shows a sign. The falling of the star thus indicates the birth of Saviour. ${ }^{59}$

\footnotetext{
${ }_{57}^{56} \operatorname{BETZ}($ n. 3) 51-52.

${ }^{57}$ Hist. 1. 107, 1. 108, 1. 120, 1. 128, 1. 132, 1. 140, 7. 19, 7. 43, 7. 113, 7.191.

${ }^{58}$ Middle Persian apocalyptical text preserved in a Middle Persian version in Pahlavi script. See WeSt, E. W.: Sacred Books of the East. Vol. V. Oxford 1897.

${ }^{59}$ WIDENGREN, G.: The Sacral Kingship of Iran. In The Sacral Kingship [Studies in the History of Religions; Supplements to Numen, 4]. Leiden 1959, 242-257.
} 
Therefore, Matthew's Gospel seems to recall the Pahlavi tradition in order to convince the Zoroastrian adherents that Jesus was the Savior their prophecies talked about.

Whatever Matthew's intention was, the star plays an important role, indicating the joyous event of a divine birth. Therefore, the magical papyrus seems to be influenced by this long tradition. We should not forget that this tradition already begins with ancient Greece where the immortalization of many humans involved their transformation into stellar bodies.

\subsection{Danger ${ }^{60}$}

The last element I wish to emphasize is the lethal danger of the proximity of the god. The magicians were aware of this hazard and also wore carefully made amulets, engraved with scenes and legends which ensured that a particular god would come in the mood for a "good encounter". This euphemism was applied to more awesome divinities, and above all Hecate and other fierce visitors by night. By invoking a god in a particular mood, mortals could limit the dangers of its presence. ${ }^{61}$ It is also telling that almost all the spells for the revelation of a god, like the spell of Pnouthis, end with a release which magicians never omit to cite even in the most briefly described spells. Moreover, there are parts of the $P G M$ where the danger, always present in magical rituals aiming at a divine manifestation, is explicitly mentioned. In PGM IV 2505 the scribe suggests an amulet because "the goddess is accustomed to make airborne those who perform this rite unprotected by a charm and to hurl them from aloft down to the ground. So consequently I have also thought it necessary to take the precaution of a protective charm so that you may perform the rite without hesitation. Keep it secret." In PGM IV 570 it says: "So when you see that the world above is clear and circling, and that none of the gods or angels is threatening you, expect to hear a great crash of thunder, so as to shock you." Approaching the divine improperly or without precautions can have deadly results. The magic spells could perhaps manipulate the god's power to prevent him from turning against the practitioner but the fear of something going wrong was always present.

Based on the above notes regarding isolation, we can assume that this fear of the gods seems not to be a purely Greek or Egyptian belief. The fear of the gods, of course, exists as a concept among the Greeks, who were also deeply concerned to avoid in any ways of committing hybris and being defiled, which causes wrath and punishment, the tisis, of the gods. However, Greek gods were not necessarily aggressive when they manifested themselves. There was no problem in someone seeing the gods. Greek gods always punished behavior that crossed the permitted limits but almost never punished a person only because he wanted to come in touch with them or did so accidentally. The only exceptions to this were the cases of Acteon and Semele,

\footnotetext{
${ }^{60}$ Some ideas about this chapter are treated in detail in CHRONOPOULOU, E.: El Oficio Peligroso del Mago. In SuÁreZ, E. - Blanco, M. - Chronopoulou, E.: Los papiros magicos griegos: entre lo sublime y lo cotidiano, Los papiros mágicos griegos: entre lo sublime y lo cotidiano. Madrid 2015, 13-30.

${ }^{61}$ LANE FOX (n. 13) 116-117.
} 
Dionysus' mother, who was consumed in a lightning-ignited flame when Zeus came before her as god and not in human form, upon her petition. These are the only attestations we have that seeing a god could be extremely dangerous, but both are very particular exceptions and do not comply with the religious credo.

It is also little plausible to trace this attitude of fear to the remains of an Egyptian influence. The Egyptians were accustomed to looking at gods. Egyptian people feared the consequences of their wrath but they did not fear their vision. In general, the gods of the Egyptians resembled those of the Greeks. In his Reallexikon, Bonnet writes that in Egyptian religion fear is not an important element. ${ }^{62}$ To the Egyptians, the gods revealed themselves as benefactors, which had formed the air, as the creators of all and the guarantors of human life, sharing happiness and inner perfection.

The fear towards the divine seems to belong to the Jewish religion. As a monotheistic religion, Judaism was inevitably more introverted. In Jewish texts, God never appeared in person on earth. The instructions for the service of the priests in the tabernacle refer on numerous occasions to the danger inherent in approaching the divine. In Exod. 4:24-26 God attempted to kill Moses without reason and, generally, in the Bible we can find many examples where the fear of the danger of approaching the divine is present. ${ }^{63}$ In Exod. 33:20 God says to Moses "No man can see me and live", which is an explicit threat or a warning.

We can find analogous fears in Sepher Ha-Razim.

I, N son of N, present my supplication before you, that you will appear to me without (causing me) fear, and you will be revealed to me without causing me terror, and you will conceal nothing from me and will tell me truthfully all that I desire. (Fourth Firmament, 63)

I adjure you by the One who formed you for His splendor and His glory to illuminate His world and who gave you rulership of the day that you will not harm me and will not terrify me. I shall neither fear nor tremble and you will return to your course in peace when I release you and you will not pause in your course from now on forever. (Fourth Firmament, 71)

\section{CONCLUSION}

It is of course obvious to stress that magic has been discussed in comparison with, and in sharp contrast to, religion. Although much has been written in an effort to define the nature of magic and to find the separating line between magic and religion, this paper, once more, has proved that magic is a social phenomenon strongly connected with religion. Better said, it is inscribed in the circle of religion. This paper aimed to exhibit a number of recurrent religious motifs of theophanies around which

${ }_{62}^{62}$ BONNET, H.: Reallexikon der Aegyptischen Religionsgeschichte. Berlin 1952, 197.

${ }^{63}$ SAVRAN (n. 2) 190-204. 
magical theophany narratives are constructed, in order to demonstrate that magic was and perhaps is in constant dialogue with religion and somehow dependent on it.

On the other hand, although the comparative approach to a phenomenon is usually condemned as incomplete and much has been left to say, it remains useful. In the case of magic, its multifaceted nature does not facilitate its understanding. Moreover, the effort to discover the aetiological functions between analogies and influences and to detect the cross-cultural links for a phenomenon that comes from an era characterized mostly by the lack of concrete religious identity is even more problematic, but also challenging. The centuries of Late Antiquity can be schematically described as a theological triangle between Greece, Egypt and Israel, without ignoring pressures by other religions originating in the Near East. The result was a religious synthesis reflected in the $P G M{ }^{64}$

However, this survey reinforces the consensus that the influence of the Jewish tradition, not only of Jewish magic but also of the sacred books of Judaism, is more than explicit in the amalgam of the $P G M$. Divine manifestations, or epiphanies, were not of great scarceness in the framework of Egyptian or Greek religion and they could plausibly be adopted in a magical context and their motifs be adapted by the magicians in the territory of Imperial Rome. However, the fact that worshipers of polytheistic religions could be influenced or at least could incorporate elements of a strictly monotheistic religion, confirms, perhaps, what Robert Turnbull had written: "Over the political and equally idolatrous faith of Rome passed a spirit of change and dissolution. Superstition enough remained, but all earnest and coherent faith, even in idolatry, was breaking to pieces and vanishing way." 65

\author{
Eleni Chronopoulou \\ Pompeu Fabra University \\ Departamento de Humanidades \\ Ramon Trias Fargas 25-27 \\ 08005 Barcelona, Spain \\ eleni.chronopoulou@upf.edu \\ xylokera@hotmail.com
}

\footnotetext{
${ }^{64}$ The term used so far was "religious syncretism". However, the more we study these texts, the more we realize that the religious elements are put together, mixed, but not syncretized. They preserve their autonomy and that is why I choose the more general term "religious synthesis".

${ }^{65}$ TuRnBull, R.: Theophany: Or, The Manifestation of God in the Life, Character, and Mission of Jesus Christ. New York - Boston 1849, 1.
} 